\title{
Mental Heath as a Weapon: Whistleblower Retaliation and Normative Violence
}

\author{
Kate Kenny ${ }^{1} \cdot$ Marianna Fotaki ${ }^{2} \cdot$ Stacey Scriver ${ }^{3}$
}

Received: 27 November 2017 / Accepted: 29 March 2018 / Published online: 17 April 2018

(c) The Author(s) 2018

\begin{abstract}
What form does power take in situations of retaliation against whistleblowers? In this article, we move away from dominant perspectives that see power as a resource. In place, we propose a theory of normative power and violence in whistleblower retaliation, drawing on an in-depth empirical study. This enables a deeper understanding of power as it circulates in complex processes of whistleblowing. We offer the following contributions. First, supported by empirical findings we propose a novel theoretical framing of whistleblower retaliation and the role of mental health, which draws upon poststructuralist psychoanalytic thinking. Specifically, we highlight how intra- and inter-psychic affective and ambivalent attachments to organizations influence the use of normative violence in cases of whistleblower retaliation. The second contribution is empirical and builds upon the existing literature on whistleblower retaliation by highlighting how organizations position whistleblower subjects as mentally unstable and unreliable individuals, to undermine their claims. We conclude by highlighting the implications of normative power for the outcomes of whistleblower struggles.
\end{abstract}

Keywords Affect $\cdot$ Butler $\cdot$ Mental health $\cdot$ Normative power $\cdot$ Organizational violence $\cdot$ Retaliation $\cdot$ Whistleblowing

\section{Introduction}

Whistleblowing is now globally accepted as an effective instrument for battling corruption (European Commission 2014; OECD 2012). Not only do whistleblowers speak up for the public interest, but their disclosures can prevent massive reputational and financial damage to their organizations if the wrongdoing is dealt with internally (Morrison and Milliken 2003). Corporate scandals involving Enron and Worldcom, and the BP Gulf disaster, demonstrate clearly

Kate Kenny

k.kenny@qub.ac.uk

Marianna Fotaki

Marianna.Fotaki@wbs.ac.uk

Stacey Scriver

stacey.scriver@nuigalway.ie

1 Queen's Management School, Queen's University Belfast, Belfast, UK

2 Warwick Business School, University of Warwick, Coventry, UK

3 School of Political Science and Sociology, NUI Galway, Galway, Ireland the detrimental effect of silencing wrongdoing (see also Mansbach 2011).

Their clear importance for society notwithstanding, whistleblowers can often find themselves the target of retaliation within their organizations. 'Whistleblower retaliation' is an organizing concept in the literature that encompasses research on the methods by which whistleblowers are punished for disclosures. Types of retaliation can range from job loss to demotion, and decreased quality of working conditions (Dworkin and Baucus 1998; Ethics Resource Centre 2012; Lennane 1996/2012; Mesmer-Magnus and Viswesvaran 2005; Rothschild and Miethe 1999; Vandekerckhove et al. 2014; Vandekerckhove and Tsahuridu 2010). A key area that remains under-researched involves theoretical developments that capture the complexity of power as it operates in situations of whistleblower retaliation. Thus far, studies have tended to adopt a 'resource-based' approach to this issue inspired by Pfeffer (Miceli and Near 1994; Near and Miceli 1985, 1986; Rehg et al. 2008). This sees power as a zero-sum entity, something that an organizational actor either possesses or does not. While useful, such theorization represents a somewhat limited view of power in the context of whistleblowing that requires further development in order to account for the complexity of the process 
of whistleblowing including retaliation (McLain and Keenan 1999; Vandekerckhove et al. 2014). In particular, these theories would benefit from considering in more depth the ways in which power can operate through diffuse networks of discourse and normative exclusions. Organizations utilize different forms of power to discipline individuals who they see as transgressors of norms of silence, while whistleblowers attempt to resist these (Premeaux and Bedeian 2003) and yet conceptual understandings remain limited. This is because extant theories disregard the psychosocial dynamics of power flows as these occur in organizations. Specifically, there is no attention paid to how the wrongdoing organizations deploy various discourses including that of mental health, to undermine the claims of whistleblowers who often internalize and enact these. In this article, we contribute to research on this important issue by drawing on Judith Butler's 'recognition-based critique' of subjectivity and power, a growing area of interest in organization studies (Riach et al. 2014, p. 1679; see also Borgerson 2005; Harding et al. 2014; Kenny 2010, 2017; Riach et al. 2016; Tyler and Cohen 2008). This view builds on the resource-based approach because it sees power as inherent to the very formation of the subject, as she constructs a sense of self through identification with discourse, rather than simply an entity that is either possessed or not. Thus, power is both complex and multiple, circulating between the person being retaliated against and the organizational representatives involved, and this enriches our understanding of power in the scene of whistleblower retaliation.

We draw our inspiration from theories of subject formation from poststructuralist and psychoanalytic thought, to conceptualize deployments of the mental health discourse in whistleblowing as normative violence. Normative violence is a term describing the violence inherent to the operation of discursive categories, relating both to the formation of subjectivity and also to the facilitation of more overt 'typical' forms of violence (Butler 1990; Chambers 2007). We see retaliation against whistleblowers as involving both kinds. To understand people's experiences of whistleblowing, we conducted an in-depth empirical study of people who spoke out in diverse sectors and country contexts. Using a variety of methods including interviews, feedback workshops and document analysis we explored individuals' interpretations of their experiences, which we analyzed alongside the proposed theoretical framework to highlight the role of discursive power in organizational retaliation. Our analysis suggests that issues pertaining to retaliatory violence including individuals' exclusions from their organizations, and their subsequent labeling as unstable, affect their mental health and negatively contribute to the outcome of whistleblower struggles. We theorize these, by highlighting how intra- and inter-psychic affective and ambivalent attachment to such discourses by those who speak up, influences the use of normative violence by organizations in cases of whistleblowing.

We offer the following contributions. First, we add to the literature on whistleblowing retaliation in which in-depth exploration and theorization of the role of power in ethical disclosures remains scarce. Specifically, we show how whistleblowers' well-being and their mental health can suffer because of experiences of exclusion from subject positions relating to their employment held prior to whistleblowing, and how organizations use the symptoms of this suffering to discredit them. We also highlight the complex dynamics by which whistleblowers struggle to understand the chaotic experiences of retaliation, which simultaneously causes them to embrace a stigmatized identity as a whistleblower. These empirical observations are analyzed through a poststructuralist psychoanalytic lens which helps us to see how a whistleblower can become passionately attached to dominant organizational discourses, which cause one pain even as they offer a sense of self by validating one's identity as a whistleblower. Butler's concept of normative violence helps us to understand this phenomenon. Overall this study contributes to the literature on whistleblower retaliation by offering a more in-depth and nuanced theoretical understanding of power as conditioned and underpinned by affect in organizational settings.

\section{Whistleblower Retaliation and Power}

Those who speak out about risky practice, illegality or dangerous activities in their workplace can be at risk of retaliation from colleagues or employers (Burrows 2001; Premeaux and Bedeian 2003; Wilmot 2000). Organizational retaliation is a common response to whistleblowing (Bjørkelo 2013; Mesmer-Magnus and Viswesvaran 2005; Paul and Townsend 1996; Rehg et al. 2008) and appears to be increasing (Miceli and Near 1992; Ethics Resource Centre 2014). Following Rehg et al., we define it as 'undesirable action taken against a whistleblower-in direct response to the whistle-blowing - who reported wrongdoing internally or externally, outside the organization.' (2008, p. 222). Reasons for retaliation vary; managers can feel deeply threatened by whistleblowers (Martin and Rifkin 2004a, b; Miethe 1999), retaliation can be deployed as a means of deterring other potential whistleblowers in the organization (Armenakis 2004; Ewing 1983; Vandekerckhove et al. 2014; see also Markova and Folger 2012), while both employers and co-workers can resort to reprisals to protect the reputation of specific colleagues (Bolsin et al. 2005; Near et al. 1993) or the organization itself (General Medical Council 2015).

Retaliation can take a number of forms (see Lennane 1996/2012; Miethe 1999; Parmerlee et al. 1982 for a comprehensive overview) including demotion, decreased quality of working conditions (Ethics Resource Centre 2012; 
Lennane 1996/2012; Mesmer-Magnus and Viswesvaran 2005; Rothschild and Miethe 1999; Vandekerckhove et al. 2014), threats by senior staff, the allocation of menial duties to the whistleblower such that their job becomes degrading, harassment, referral to psychiatrists (Martin and Rifkin 2004a, b), outright dismissal from work and prolonged legal challenges. The whistleblowers we studied reported many such occurrences. Retaliation can also include tactics aimed at stigmatizing the individual, for example through character assassinations or accusations of being disgruntled employees, spies, or 'squealers' (Worth 2013), which are sometimes supported by the media (Jubb 1999; Near and Miceli 1985). These tactics are facilitated by ambivalent perceptions of whistleblowing in wider society; it is often seen as a 'morally ambiguous activity' (Thomas 2005, p. 147). While some view it as heroic (e.g., Grant 2002), others see whistleblowing as a traitorous violation of loyalty to one's organization (Hersch 2002). Whistleblowers are often 'treated as disturbed or morally suspect' (Alford 2001, p. 104). Not least because of this ambivalence in how they are perceived, retaliatory tactics can be successfully applied by the wrongdoing organizations and can have impacts on whistleblowers' well-being, often causing stress and disrupting one's sense of self.

Various theories of power have been deployed to study the nature and extent of retaliation experienced by whistleblowers. Of these, a perspective derived from Pfeffer's resource-based view has tended to dominate (Near and Miceli 1986). The idea is that retaliation is proportional to the balance of power between whistleblower and wrongdoer, with power classified as a resource that can be accessed and deployed in the whistleblowing struggle (Miceli and Near 1992, 1994; Near et al. 1993; Near and Miceli 1986). Potential sources of power for the whistleblower include their perceived legitimacy, e.g., through possessing a senior role, or a position in which whistleblowing is 'mandated' such as an audit or compliance function (Miceli et al. 1999; Rehg et al. 2008), and support from others within the organization (Miceli et al. 1999). These decrease the likelihood of retaliation, while perceived threats to the power 'resource' of the wrongdoer are likely to increase it (Rehg et al. 2008), for example where their actions involve potential harm to the public (Near and Jensen 1993), where the legitimacy (Miethe 1999) or future performance (Miceli and Near 2002) of the organization is being threatened or where an external reporting channel is used (Mesmer-Magnus and Viswesvaran 2005; Rothschild 2013). If, on the other hand, the wrongdoing is such that it has become systemic to the organization (Mesmer-Magnus and Viswesvaran 2005), for example as part of its culture or climate (Near et al. 1993), retaliation is more likely to occur. This view of power as resource is prevalent in studies of whistleblower retaliation.
Hence, studies have focused on retaliation as a series of 'types' or tactics, or as a phenomenon whose likelihood is determined by the balance of power between whistleblower and wrongdoer, in which the control of critical organizational resources by each party is key (Rehg et al. 2008). In recent years, however, whistleblowing has been shown to be a more complex process than previously assumed, involving a series of interactions between the discloser and members of the organization (Martin and Rifkin 2004a, b; Vandekerckhove et al. 2014). These interactions shape both the position and also the self-understanding of the actors involved. Thus, power is also something that circulates between these parties and is constitutive of their engagements, rather than simply a resource that is either held or not. It appears vital therefore to build on existing work and propose new theories that enable an understanding of these dynamics of power as they play out within the complex and mutually constitutive set of interactions that make up the process of whistleblowing. To date there have been few theoretical framings that understand power in whistleblower retaliation as circulating between both whistleblower and 'retaliator,' enacted by both and owned by neither, that sees whistleblowers both engaging in power activity while also resisting it. The complex dynamics of discursive power and its role in how social norms are deployed to legitimize the ostracization of whistleblowers on the one hand, and whistleblowers' engagement and participation in such dominant and disciplining discourses on the other hand, have not yet been theorized, despite their value in providing a fuller account of whistleblowers' experiences. In this article, we develop this notion of normative power focusing on how organizations exclude dissenting individuals through mental health discourses, which are deployed by whistleblowers themselves in an affective process that allows them to assume a viable subjectivity. This, we argue, helps us understand the subtle operation of normative power in organizations.

\section{Whistleblower Retaliation and Mental Health}

The concept of 'mental health' has been used in recent years to understand a variety of experiences (Foucault 1976/2006). It has become a dominant interpretive framework with concomitant terminology, academic disciplines and medical practices (Walker 2006). In whistleblower research discourses of mental health are also drawn upon to understand and to describe the severe consequences of whistleblower retaliation. Researchers, for example, note instances of depression and symptoms analogous to post-traumatic stress disorder (Bjørkelo 2013), categorizing these as mental health impacts. Retaliatory tactics can lead to anxiety and feelings of isolation (Bjørkelo 2013), along with sleep difficulties (Jackson et al. 2010; Peters et al. 2011) and in some cases suicidal feelings (Lennane 1993). These negative 
mental health symptoms appear following disclosures, with many whistleblowers described as previously 'high-achieving, respected' and committed employees (Rothschild 2013, p. 653). In her pioneering work surveying the postdisclosure experiences of 35 individuals who contacted Whistleblowers Australia, Jeanne Lennane reports on the causes of such issues, including being removed from normal work duties or required to fulfill overly demanding tasks, being isolated from colleagues and/or referral to a psychiatrist. She finds that the stresses accompanying whistleblowing can cause people to lose their livelihoods and to experience marital breakdown, substance abuse and bankruptcy relating to expensive lawsuits (Lennane 1996/2012). Even where not referred to psychiatric counseling by their organizations, many whistleblowers seek it to help them cope (Alford 2001; Rothschild and Miethe 1999). The stigma associated with 'mental illness' in society (Corrigan 2005) can be used by retaliatory organizations seeking to discredit a whistleblower. Both the lived experiences of people and the paradoxical response of society combine to make whistleblowing a very stressful endeavor with concomitant negative impacts on people's well-being. However, there have been few studies focused on this linkage between discourse and practice, showing how understandings of the lived experience of whistleblower retaliation draw upon norms relating to mental health, and how these might be internalized by the whistleblowers themselves. We turn to poststructuralist psychoanalytic theory which has been applied to deal with issues of power and exclusion in relation to normative frameworks of gender, crime (Holloway and Jefferson 2000), public health (Fotaki 2014), psychiatric care (Rizq 2013), race (Hook 2007), among many others, to address these issues. Such framing allows us to consider how discourses shape our subjectivities through psychic internalization. This perspective conceives of people as socially situated subjects whose sense of self is molded by flows of discursive power, and it has the potential to offer novel insights for theorizing the role of normative power in the context of whistleblowing.

\section{A Psychosocial (Poststructuralist and Psychoanalytic) Approach to Power and Retaliation}

To explore the complex dynamics of power as it circulates in and between subjects in instances of whistleblower retaliation, it is useful to draw upon Foucault's poststructuralist account of discursive power which has been influential in organization scholarship to date (Townley 1993; Knights and McCabe 2003). Under this view, power is inherent to the formation of the subject; people identify with discourses that both enable them through providing a sense of identity, but constrain them in circumscribing what is possible.
This approach has shed light on how employees can be subjected to powerful discourses, such that they are effectively controlled and disciplined by these (Barratt 2003; Hardy and Thomas 2015; Knights and McCabe 2003; Rhodes and Wray-Bliss 2013; Roberts 2005; Townley 1993).

Foucault's theoretical account, while insightful, is limited in its ability to illuminate the specific dynamics of subjectification, on what happens at the level of the subject's psyche when they engage with power (Mumby 2005; Newton 1998), or as Roberts (2005) describes, the moment 'in which subjectivity becomes "inextricably entwined" with power/ knowledge' (Roberts 2005, p. 620). Foucault's account is also critiqued for ignoring affect in such dynamics (Hook 2007). Recently scholars have proposed that Lacanian, "poststructuralist' psychoanalysis offers a useful contribution, shedding light on Foucauldian subjectification by accounting for the contribution of psychic dynamics in this process (Pavon-Cuellar 2010; Stavrakakis 2008). Butler's Psychic Life of Power has been particularly influential in introducing such ideas to organization studies (Riach et al. 2014; Harding et al. 2014). She describes subjects' psychic desires for recognition within the symbolic order as fueling an ongoing quest for new and more promising affective identifications (Butler 1997a, b). There is no subject prior to their interpellation by discourses within the social. Coming into being, we desire recognition from elements of our social worlds, including the people close to us (colleagues, family members) but also from symbolic, abstract notions including our professional associations or personal ethics. This recognition is necessary before we can be accepted as viable social subjects; without it we are non-existent in our social milieu (Butler 1997a, 2004a). Subjects are therefore 'constituted through norms' that define the terms in which they can be recognized. The denial of recognition is thus catastrophic as it threatens the subject with 'symbolic extinction' (Butler 1997a, p. 7). Seeking to avoid such consequences, she suggests, we are compelled to subject ourselves to norms that potentially cause us pain:

Called by an injurious name, I come into social being, and because I have a certain inevitable attachment to my existence, because a certain narcissism takes hold of any term that confers existence, I am led to embrace the terms that injure me because they constitute me socially (Butler 1997a, p. 104)

There is a paradox inherent to 'injurious interpellation' (Lloyd 2005, p. 451); the same trauma of subjection that offers us a place in the social can simultaneously cause us pain. We are effectively 'un-done' by our affective desires for being recognized as valid subjects: 'the subject produces its coherence at the cost of its own complexity' (Butler 1993, p. 115). The organizations we work for can contribute to such 'undoing'; workplace norms have a strong influence 
over our sense of self not least because organizational rules and processes tend to 'fix' subjects into position, even where this is unwilled (Riach et al. 2016). Roberts describes organizational leaders' experiences of being refused recognition by management discourses alongside the subsequent control that such denial exerts: 'the refusal [of recognition] contains the employee by robbing him/her of a sense of existence and capability' (2005, p. 634). This is crucial for understanding how whistleblowers adopt the identity of excluded individuals or even unstable mental health victims after they are denied their identity as capable and successful professionals.

A further contribution to Foucauldian understandings of subjectivity is the concept of affect (Butler 1997b; Hook 2007; Stavrakakis 2008). In Butler's reading of Foucault via Lacan, it is our desire for subjection that leads us to be 'passionately attached' to norms. The subject 'responds to reflections of itself in emotional ways, according to whether that reflection signifies a diminution or augmentation of its own possibility of future persistence and life' (Butler 2004a, p. 235, emphasis added). Butler describes the 'passion and grief and rage we feel' as part of subjectification, affects that 'tear us from ourselves, bind us to others, transport us, undo us...' (2004a, p. 20). In this way, affective subjectification is 'radically external' to the self; rather than being an 'internal' phenomenon it acts as a 'technology of subjectivity' that links subjects to wider social structures (Hook 2007, p. 270). Such insights notwithstanding, affect tends to be overlooked in poststructuralist accounts of subjectivity within organization studies (Stavrakakis 2008) despite some exceptions (Kenny 2012, 2017; Tyler and Cohen 2008). By introducing concepts of desire, recognition and affect, Butler enriches Foucault's account of how the subject becomes 'entwined' with power/knowledge. We draw on this conceptualization to explain how stigmatization of whistleblowers as disloyal organizational members leaves them with few options: they are forced to accept the position of the wronged subject suffering from mental health problems if they do not want to position themselves entirely on the outside of the organization. In this sense, they retain some paradoxical sense of attachment to their organization.

More recently Butler's work explores how powerful discourses proliferate by matrices of exclusion that define who is 'in' and who is 'out,' through the recognition that they confer (Butler 2004a), noting that this can cause suffering for those 'de-realized subjects' who are left outside. Perceived to be neither grievable nor valuable, such lives are precarious, more vulnerable to violence than other subjects (Butler 2004a, 2009, p. 25). She analyzes this exclusion of subjectivities in the case of victims of the US-led conflicts in Iraq and the Middle East who are cast as threats rather than as humans who deserve protection from illegitimate state violence. Butler conceptualizes this as 'normative violence,' a kind of violence engendered by the play of norms that can create exclusions and foreclose subjectivity (2004b), sometimes facilitating more 'typical,' overt, forms of violence including physical forms (Butler 1990, 2004a, b) and acting as a prerequisite to these (Chambers 2007). Overall these ideas show precisely why we are vulnerable, as subjects, to dominant discourses and the impact of being excluded from them.

Reflecting on how exclusionary violence also relates to work organizations, Butler describes the '...the arbitrary and violent rhythms of being instrumentalized as disposable labor' (Butler 2009, p. 41). She shows how such practices are effective because capitalist forms of organization elicit from us the kinds of passionate attachments to dominant social norms, values and rules, which are re-affirmed and re-embedded through circulating discourses in ways that ultimately represent normative violence, suggesting that power is both an intra (psychic)- and intersubjective (social) process rather than a property or attribute that one can obtain at the expense of the other. While Butler does not expand on this in the context of work organizations, others have recently illustrated how her 'recognition-based critique of the conditions governing viable subjectivity' (Riach et al. 2014, p. 1679) can shed light on dynamics of normative power in organizations (Borgerson 2005; Harding et al. 2013, 2014; Riach et al. 2016), not least in relation to sexuality and gender (Tyler and Cohen 2008) but also the consumption of management textbooks (Harding 2003), ethical workplaces (Kenny 2010) and organizational violence (Varman and Al-Amoudi 2016). This theory has recently been applied to understand the experiences of whistleblowers in the aftermath of their disclosures (Kenny 2017) and their exclusions from recruitment practices and friendship circles because of having engaged in 'impossible speech.' It has not yet been utilized in studies of whistleblower retaliation and mental health.

Overall, this view of power has the potential to add to understandings of whistleblower retaliation. Here power is more than a resource, something we either possess or do not; rather it is multiple, complex and implicated in the very formation of the subject by psychic desires for recognition. In this article, we show how a poststructuralist and psychosocial perspective can illuminate the ways in which specific discourses of mental health can come to construct whistleblower subjects even as they threaten their wellbeing and are actively resisted by subjects themselves. The proposed framing builds on existing understandings of power dynamics to provide more nuanced insights on whistleblower retaliation and explain how normative violence arises in organizations. 


\section{Methods}

\section{Data Collection}

We carried out qualitative interviews with twenty-two whistleblowers in the USA and Europe. Using a semistructured approach, our aim was to enable people to 'tell their story' in their own words. Initial interviewees were sourced through a variety of means including online searches for the term 'whistleblower' and 'whistleblowing' but also through our contacts in whistleblower networks and advocacy groups. After this a snowball methodology emerged; as we developed relationships with individuals, explaining our project and meeting them for interview, people typically put us in touch with others in similar situations. This sampling method has limitations but was chosen because of the difficulty in gaining access to whistleblowers by other means. A psychiatrist and psychoanalyst with direct experience of working with whistleblowers was also interviewed, and two respondents were interviewed twice, yielding twenty-five interviews overall. Prior to each interview, newspaper articles, court transcripts and secondary interviews were gathered for analysis, and a brief interview guide was prepared. The emphasis was on the interviewee's free-flowing responses; interviewers followed the direction of the 'conversation' and asked for clarity or more detail where needed. Interview durations ranged from $30 \mathrm{~min}$ to two hours and all were recorded before verbatim transcription.

Whistleblowing can be a difficult and often harrowing process, and we were initially concerned that our request that people revisit such experiences during the interview would cause distress. In line with the ethics requirements of our institutions and funding body, we provided participants with full information on the aims and background of the study before they took part, along with details of available supports if distress should occur, including peer support. Consent was sought for participation and publication of results. We found that interviewees had already engaged in significant reflection upon on their experiences and were comfortable articulating them. People reported that participating in this study was a positive and helpful experience, as is also seen in other studies of vulnerable populations (Biddle et al. 2013).

\section{Data Analysis}

Following Foucault, we acknowledge that the construction of research 'knowledge' through categorization of data is itself a form of power, and we recognize that insights are generated rather than 'uncovered' during the research process (Riach et al. 2016; see also Harding 2008). However, some way of making sense of our vast and complex data set was necessary. An inductive, iterative approach was used for analysis of the data, progressing through multiple phases and encompassing ongoing reflection by all researchers (Hammersley and Atkinson 1995, p. 24).

We began with 'cold reading' of the transcribed data by Researcher 3 who has broad knowledge of whistleblowing but who was not involved in data collection. The aim was to allow commonly expressed concepts and themes to emerge (Richards 2005, p. 94). These included self-perceptions, support systems, personal qualities and impacts, with mental health as a subtheme of the latter. The qualitative software tool, MAXQDA, was used to organize these. An initial 'data report' (18 pages) was compiled illustrating each theme and subtheme with anonymized excerpts. This report was presented at two separate whistleblowing workshops in the UK (January and June 2015), to which interviewees were invited. Initial versions of the current article were developed and submitted for review. The impact of retaliation on whistleblowers' well-being and stress levels was a frequent topic for discussion at the workshops and was a dominant feature of the data encompassing over one quarter of the coded text, or 28,025 words. We had coded this as 'mental health impacts,' noting that it was not typically addressed in the existing literature.

The next stage involved delving deeper into the theme of 'mental health' in the context of exclusion and ostracization by examining the data pertaining to this. We drew on other scholars inspired by poststructuralist psychoanalysis (Harding et al. 2014; Riach et al. 2014, 2016) and began with a close reading of data, followed by open coding. We were interested in the ways in which 'identities are constituted within circulating discourses,' such that discourses “"speak through" subjects' self-reflections. We therefore focused on how people referred to themselves in the first person (Harding et al. 2014, p. 1217), finding people's deployments of the 'I' as a 'place-holder' to be useful in examining subjection to a variety of discourses (Harding et al. 2014, p. 1217). We remained attentive to how the 'I' drew on dominant discourses that appeared to offer validation (Parker 2005, p. 173). Such an approach facilitates an opening-up of aspects of organizational life that are typically taken for granted, and can help analyze the kinds of 'organizational undoing' that subjected selves undergo as they engage with the organizations for which they work (Riach et al. 2014). Dominant sub-themes emerged in relation to mental health and people's accounts, and these were noted alongside the identified contradictions. We attempted to highlight and discuss these 'states of disagreement' (Parker 2005, p. 175) rather than to force a falsely coherent account upon the data (Hook 2007).

While the previous phase focused on our participants, the final step in our analysis involved an 'undoing' of our 
involvement in the research process. Organizational research reflects researchers' own understanding of participants' experiences and thus can act to fix research subjects into particular categories (Ainsworth and Hardy 2012). It was therefore important to interrogate our own framings (Gilmore and Kenny 2015; Riach et al. 2014; Wray-Bliss 2003) and to engage in reflexive critique of how we were positioning ourselves and our subjects as the research progressed. As a team, we reflected on our own engagements with discourses of exclusion, and of whistleblowers' suffering in the context of mental health: how these influenced our approach to the study, our conduct during it and our subsequent representation of the research. We include these reflections in our findings.

\section{Findings}

This study focused on understanding the play of discourses of mental health and retaliation as they appeared to circulate both within the organizations that deployed them and through experiences of whistleblowers. We weave theoretical analysis throughout our presentation of data to build on our findings as the article progresses while accounting for our co-implication as researchers in constructing these findings.

\section{The Fragmenting ' $\mathrm{I}$ ' and the Whistleblowing Subject Suffering}

People reported negative impacts to their well-being resulting from organizational retaliation, often in terms of a sense of self that was falling apart. Georgia ${ }^{1}$ had worked for a large financial institution in Ireland. Her immediate boss had been engaged in illegal lending and other kinds of malpractice. When this man accused her friend of transgressions that he himself had carried out, Georgia decided to testify in court, and speak publicly on national television about what she had seen. Dubbed a whistleblower in the media, retaliation came in different forms. First, her employer actively pursued her partner, who worked for the same financial institution, for repayment of outstanding loans:

What they did, because obviously they wouldn't give him the finance to finish the houses....then they sacked him, so he didn't have a source of income. And they were threatening him because obviously if you don't have any money, you can't pay the mortgage and yet they were threatening etc., etc., over arrears ... [My partner] wouldn't get out of bed, he was really suffer-

\footnotetext{
${ }_{1}$ All participants have been anonymized.
}

ing, just depression....I don't know if it was depression but it was pure fear. He wouldn't eat....he'd sit up all night and then he'd go to bed all day [Georgia]

Georgia was bullied in numerous ways including ritual humiliation in front of colleagues and being subject to micro-management. She describes feeling that she was being 'stripped apart' when she faced a legal team from her former employer. She had attempted to prove that retaliation had taken place against her and her partner.

To prove anything like that, it was really, really stripping me apart. I had to have everything, but how do you prove that? You have to be so [sure], one hundred per cent sure that everything is right...[Georgia]

Shortly after this, she began to experience ostracization in her local town as people associated her with the corruption scandal, not least because her former boss was considered a charismatic and successful 'rogue,' prior to the full extent of his wrongdoing becoming public:

There are people... across the road who won't speak to me. And another man who kept telling me, you know, "What you should do is, you should leave the country, just leave the country, leave the country..." Like, you tell me to leave the country like, "go!" A lot of people are like that [Georgia].

She describes how she reacted to hearing that national newspapers had printed her name in relation to the story for the first time:

Actually, a friend stayed with us the night of the [TV programme] and he said I am going down to the shop the next day. And I get up and all the papers [are there], and I was like....Ahhhh! Yeah, like I'd get palpitations and a few panic attacks when that used to happen, and I opened that front page [Georgia]

Georgia's experiences of retaliation caused her much stress. She had come to occupy the subject position of 'whistleblower,' and this had led to retaliation against her, which was experienced as a source of pain. Her sense of self was being challenged and attacked as retaliatory tactics eroded her previously held recognition as a valid subject (Butler 2004a, b).

Peter was made redundant from his large UK bank for speaking up about dangerous lending practices. A senior executive in charge of risk at the bank, he had led a team overseeing the culture in various departments. Having become aware of dangerous norms of risk-taking particularly in sales, he repeatedly issued reports and attempted to raise the problem at board level. He was assured that these would be addressed by his chief executive, but on return from a holiday in September 2005, he learned that he had been made redundant. A common retaliation in 
whistleblowing cases involves either being dismissed, or being pressured to resign after having spoken up. Peter brought a case against his organization for having been illegally fired as a genuine whistleblower. An independent report was commissioned, and the bank's own audit firm was tasked with carrying it out. Ostensibly the report was about the malpractice Peter had described, but in practice it focused on him. It concluded that he was a difficult person to work with: unreasonable and overly emotional. He was shocked to read it:

It was devastating. Can you imagine being described like that...? When you set out to do your job to the best of your ability? [Peter]

He describes the days and months afterward as having extreme effects on his well-being:

My mental and emotional health was in very bad shape. I was a mess. I could not think straight anymore. My armpits sweated profusely almost all the time. I was drinking like a fish. I was not sleeping. I was a train-crash. [Peter]

Sometimes employees are asked to leave the organization temporarily, to take sick leave or 'gardening leave,' while the dispute is ongoing. Michael, who blew the whistle on money-laundering at his US firm, describes what it was like to have been removed from one's organization, particularly how this can impact upon one's mental well-being:

You are not at work, right? You're at home, right, because you're on sick leave or because you're on ... anyway. So, all day long, you're churning this. You're not sleeping right, whereas they've got a job to do and they're not thinking about it at the same intense levels and at the same analysis that you apply to it... [Michael]

He notes that this situation of being left out can make one feel rather paranoid and obsessed:

And then you tend to get this self-obsession, some degree of paranoia, considerable judgment [of others], which isn't necessarily the best [Michael]

His temporary removal from colleagues emerged as a key source of stress in numerous interviews. Contributing to this is the fact that some whistleblowers actively isolate themselves without waiting for their colleagues to do it, sensing in advance that they will be ostracized. Michael describes how, having been finally fired from his firm for speaking out, he deliberately stayed away from most of his former friends/colleagues:

I didn't want to be going out with them on a Tuesday night only for the management to hear that, "You were out with so and so last night. In the office, tell me what he ..." and they're getting a grilling [Michael]

Here it appears that Michael is actively excluding himself, in expectation of others doing it for him. He describes how this contributes to stressful experiences of isolation. Again, we see an 'undoing' of one's sense of self through organizational retaliation, along with the anxiety that accompanies this; the destruction of people's long-held attachments to their organizations is experienced affectively (Butler 2004a, b; Riach et al. 2016).

A Swiss whistleblower, Ernst, described how he had spoken publicly about the fact that his bank's offshore subsidiary in the Caribbean was facilitating tax evasion for wealthy clients. He had released large amounts of data via WikiLeaks and was pursued by his bank through the courts for violating Swiss banking laws relating to secrecy. Other forms of retaliation included intimidating his family through continuous surveillance by private detectives, and launching a smear campaign in the media. As in many other cases, we observed the stress that this caused him:

I have been put under such mental pressure (mobbing) that I got sick... The private and family life- Article 8, 1 of the [EU Human Rights] convention- has been seriously impacted. Not only we ourselves felt strongly harassed over a time-frame of 3 years. Also, our neighbors became alienated. Our daughter and I needed mental care. [Ernst]

In an ensuing court case, the bank was reprimanded for this intimidating behavior toward Ernst and his family.

I have been exposed to what I call "psychological terror". The prosecutors demanded that I undergo three psychological evaluations by psychiatrists appointed by the Court of Zurich. Clearly, the aim was to portray me to the public as mentally ill. I declined to cooperate with the psychiatrists because I felt healthy, and because I was not allowed to have either my lawyer or an independent psychologist attending the psychiatric evaluation. [Ernst]

The mental health of employees can frequently be used by organizations defending against claims of retaliation against whistleblowers (Devine and Maassarani 2011), not least because of the stigma that tends to surround mental health issues in society (Corrigan 2005).

Tudor had been enrolled in various medical practices by his organization with the stated aim of addressing his psychological problems that arose after whistleblowing. He began to fight back against the organization because of what he had experienced both as a whistleblower but also in the aftermath, and was positioned as someone with the stigma 
of mental health issues. He felt that this was being used to negate his claim for unfair dismissal and to show that he was unreliable:

And unfortunately, by this time, the relationship had pretty much deteriorated because it was an 'us versus them' scenario. By the time they came to want to put me in front of an independent psychiatrist, they were sending me medico-legal experts, not clinicians. These were people who, you know, with a little bit of imagination on the internet, you do some background investigation and the first guy they wanted to send me to was a guy who spends his whole life writing reports for the MoD, basically saying there is no such thing as PTSD; that it's all in the mind. [Tudor]

Ironically, he felt that he was positioned as unreliable in two ways: first because of the stigma associated with mental health but also because he was perceived to claim an imaginary condition: PTSD. He suspected that this positioning was designed to strengthen the organization's case.

So from the get go, it was like, "Guys ..." So, the whole trust thing is just crumbling, you know? [Tudor]

These whistleblowers describe the various ways in which they were actively positioned in relation to mental health discourses, by their organizations. They felt that the aim was to connect them to mental health issues and thus to discredit their claim.

People's engagements with discourses of mental health were thus paradoxical; when describing their experiences, they appeared to draw upon the very terminology that was then used to cause them pain. In this way, people were effectively 'injured' by the very norms - those relating to mental health-that they simultaneously drew upon to position themselves as subjects (Butler 1997a, b). This was made more complex still by the perceived stigma relating to mental health. While organizations used mental health in paradoxical ways, to discredit whistleblowers' claims, the fact that many people went on to cite 'mental health difficulties' in subsequent court cases against their organizations-aiming to prove damage to the self that resulted from retaliation against them following their disclosure-adds further complexity to this relation.

\section{Hiding the 'Mental health victim "I"'}

We were struck by the elusive and contradictory ways in which people represented the stress that they had experienced. As noted above, many drew on discourses of mental health to exist as viable subjects and yet, examining the data in more depth shows how people simultaneously attempted to deny and hide this aspect. For instance, despite Tudor's evident suffering from significant mental health problems, which were exacerbating the difficulties of his whistleblowing claim, he felt that he had to keep this hidden from even his close friends. This was partly to do with the fact that he and his wife belonged to the same organization:

Some of that social circle know us and, you know, I was known in the bank as well and we've had to ... we've never lied to anyone but we've been economical with the truth. So, when it was known that I'd left employment at the bank, rather than telling them that I'd been sick with depression for three years, we just said, "[Tudor] took a package and left." That way, there are no questions. People don't start asking what you ... where you've been, why did this happen, you know? Because quite frankly, you know, that would be a very difficult conversation [Tudor].

Peter describes his initial response to the retaliation he was experiencing from his former bank, and his active efforts to hide it:

Did I let my anger out? For a period of time, in my soul I had anger. It was anger about people who refused to cooperate... Anger with the cultural indisposition to challenge. [Peter]

As with others, Peter learned quickly though that to be seen as angry, or display any kind of emotion when this process was going on, was a mistake and so he began to actively suppress this. Many others were keenly aware that if they engaged in any emotional 'outburst,' regardless of how minor it was, this might be interpreted by onlookers as a signpost to mental health issues. Ernst discusses the difficulty inherent to this self-censorship, particularly in situations that seemed to call forth an emotional response, for example his family's reported intimidation at the hands of detectives employed by his former bank.

This is a very difficult point for everyone who goes in that direction: emotions. You have to control your emotions, even though you know you are being harassed. [Ernst].

This suppression of any outward sign of stress was common in our study. Although Lindebaum and Gabriel (2016) had argued that anger, particularly moral anger, can have positive effects in challenging un-ethical behavior, we found that such moral anger was more often subdued by whistleblowers for fear that it would be perceived as an 
expression of 'madness,' a failure to maintain rationality and objectivity. As researchers, we found this to be the case even as we carried out our interviews; many individuals discussed their mental health struggles 'off the record,' asking us not to write about these, even though their accounts would be anonymized. ${ }^{2}$ People feared that any association might affect their credibility, weaken their claims and damage their validity as subjects. In this way, people appeared to internalize the organizational and societal norms that excluded them. Understanding how damaging it was to be seen as mentally unsound and thus 'outside' the norm of mental health, people downplayed this aspect of their whistleblowing experience. In performing their subjectivity therefore, they effectively controlled and disciplined themselves (Butler 1990).

\section{The Whistleblowing Subject and the Interviewer 'I'}

As researchers, we too contributed to the prevalence of suffering and victimization in understanding whistleblowers' experiences, through our inadvertent 'fixing' (Ainsworth and Hardy 2012) of our respondents into related categories. In the initial data analysis conducted independently by researcher 3, all information relating to stress was grouped under the term 'Mental Health.' As a team, we agreed that this was significant and proceeded to analyze the data in more depth under this conceptual category. 'Mental health' was a primary theme in our subsequent data report and initial article drafts, which we presented to whistleblower interviewees at workshops and conferences (author/s), as detailed above. As researchers, we might have therefore contributed to the presence of 'mental health' as an organizing concept around which painful experiences of isolation, rejection and self-dissolution could coalesce. Our analysis was as much about our own embeddedness in wider discourses relating to the prevalence of mental health as it was about the experiences of those we were studying - we thus perhaps unconsciously reinforced these discourses by choosing to describe the painful experiences of our respondents as 'mental health issues,' and unwittingly encouraged them to see their struggles in this way. Inviting a leading figure in whistleblowing circles, an NHS psychiatrist and psychoanalyst who volunteers at a leading whistleblower advocacy group as one of the keynote speakers for the London workshop, no doubt contributed to this. Such an individual was more likely to deploy the language of mental health to frame and understand the instances of stress-related struggle that emerged in our findings. Commentators on initial drafts of this article usefully urged us to 'un-do' our research process

\footnotetext{
${ }^{2}$ Only data for which permission has been granted for use in publications is presented here.
}

and examine our role as co-constructors in emergent conceptualizations of mental health detriment in relation to whistleblowing, and we did so through reflecting upon and interrogating our own and each others' preconceptions as described above.

\section{Discussion}

The findings presented highlight the multiple and complex ways in which discourses of exclusion, stigmatization and mental health play out in instances of whistleblower retaliation and how these impact on whistleblower subjectivity. First, subjects found themselves excluded from norms of what it meant to be a 'valid' employee and found this to be painful and stressful. This experience appeared to lead to a disintegrating of the self, as people found themselves 'stripped apart' during processes of organizational retaliation where mental health problems caused by it were then turned against them to undermine and delegitimize their claims. To reconstruct a sense of self as whistleblowers, whistleblowers paradoxically often drew upon discourses of mental health (among others), when describing themselves as victims of organizational retaliation. They did so to defend their actions and reiterate the validity of their disclosure by stressing the impact of the punitive actions against them by the wrongdoers. Ironically, however, it appeared that these very deployments of discourse were simultaneously deployed by organizations to position and 'fix' whistleblowers as unreliable and 'mad,' within a wider societal context in which mental health is stigmatized. Thus, people found themselves identifying with the very subject positions that were detrimental to them and to their acceptance as reliable truth-tellers. As a result, subjects themselves participated in the promulgation of this oppressive discursive nexus, through actively internalizing norms (Butler 2004a).

We see further complexity as people actively tried to downplay and hide this subject position, to colleagues, friends and to ourselves as researchers: silencing themselves, as with Tudor, Peter and Ernst's attempts to self-censor and hide the mental health struggles they were experiencing. As active participants in the construction of this research account, we authors are not immune from such processes; rather we made choices that further fixed the label of 'mental health sufferer' onto our research participants even as we simultaneously attempted to 'undo' it. This is because we also used the available language of mental illness to understand what our respondents were experiencing, thus contributing to their labeling and self-identification expressed in terms of the language of mental instability.

Overall, it is clear that power in the case of whistleblower retaliation is more than a zero-sum resource that is either possessed or not (Near and Miceli 1985, 1986; Rehg 
et al. 2008). While an approach inspired by Pfeffer might understand 'mental health' as a resource initially possessed by the whistleblower, around which a struggle ensues as the organization attempts to take it from them, this framing would not show the ways in which the whistleblower herself is implicated in this struggle through her own practices of identification. Nor would it highlight the powerful dynamics of affect that influence this struggle. To further develop our understanding of whistleblower retaliation and mental health, it is vital to highlight the operation of discursive power particularly in the case of long and complex whistleblowing struggles that involve a series of interactions between discloser and organization. Discursive power relating to mental health plays an important role through its proliferation by the language of science (author/s). It is performative in that it circulates within and between not only the parties involved: research participants and the organizations they have left, but also the researchers who enact this study. Discursive power provides constitutive identifications and categories that further bring discourses of mental health into being. These insights form the first and key theoretical contribution of this study, building upon previous conceptualizations in the whistleblowing literature and enriching our understanding of the experiences of retaliation not least by showing how whistleblowers themselves can be active participants in its variable deployments. This observation is not intended to 'cast blame' upon whistleblowers for their own subjectification but rather to highlight the inherently limiting possibilities for resisting power within discursive boundaries.

Our second and related theoretical contribution is to propose that affective and ambivalent psychic attachments to social discourses of abnormality and instability as part of mental health influence the deployment of normative violence by organizations in cases of whistleblowing. Thus, we build upon extant poststructuralist psychoanalytic studies of organizations that highlight how selves are 'performed' and come into being amid complex discourses. In so doing we expand our understanding of how organizational wrongdoing is perpetuated, by developing the psychosocial conception of retaliation in the context of whistleblowing. Exclusionary 'matrices of control' can operate in organizations demarcating subjects as valid or non-valid (Riach et al. 2014; Tyler and Cohen 2008), and our study highlights how subjects can be 'passionately attached' to power. Specifically, it demonstrates the affective, complex and often contradictory ways in which this can occur. Affect and emotion emanated from people's accounts as they described first the despair and anxiety that resulted from being cast outside of organizational norms, but also the ways in which they found themselves responding to the mental health-related character assassinations to which they were subjected by their organizations. As Ernst and Peter both note, it is extremely difficult not to 'act emotionally,' where one is aware that the display of emotions stands to further worsen their situation by strengthening the organization's claim that they are mentally unsound.

We also found that affective subjectification amid discourses of mental health was inherently ambivalent, taking the form of a 'tug of war': of desire for recognition, alongside the threat of exclusion and alienation (Harding 2007, p. 1977). As noted above, this demonstrates the active participation in normative violence by those very 'de-realized' subjects that were likewise excluded, albeit in complex and ambivalent ways. In addition, the interview process was itself suffused with affect. Researchers 1 and 2, who conducted the interviews, noted how drained we felt after each interview, having listened to details of severe suffering that people had experienced at the hands of seemingly benign institutions that we had known all our lives, including banks and health organizations. The hurt experienced by our interviewees tended to fill the room, hit us bodily, and it stays with us now. Reflecting on this, we note that one way of dealing with this was to code these experiences in our analysis as evidence of mental health-related suffering. This, ironically, gave us something of a sense of 'control' over information that was emotionally overwhelming. But in doing so, we were no different from our research participants who adopted the mental health discourse.

In addition to affect, we show how normative violence can be used in the performative regulation of subjection within organizations. Normative violence describes the exclusion from representation that can leave subjects vulnerable to both symbolic extinction and to physical precarity (Butler 2004b). The in-depth account presented here highlights how people were excluded first because of their attempts to speak up, which then lessened their viability as organizational subjects (see also Kenny 2017). This left them in a precarious position, even more vulnerable to symbolic violence in the form of retaliation, smear campaigns and labeling because they were already positioned as mental health sufferers. Normative violence was not simply enacted by retaliating organizations drawing on the language of mental health to undermine the character of the whistleblower and present him or her as untrustworthy and unreliable, but rather subjects participated in this violence even as they tried to defend themselves against organizational attacks. Building upon existing Butler-inspired 'recognition-based critiques' of power within organizations (Riach et al. 2014, p. 1693), we contribute insights into the role of organizations and subjects in deploying normative violence (Butler 2009; Varman and Al-Amoudi 2016). We add to existing understandings of how normative violence against whistleblowers operates through recruitment practices and social networks, postdisclosure (Kenny 2017), specifically by showing how 
this can occur where mental health is deployed in cases of whistleblower retaliation. We highlight the affective and ambivalent dynamics therein.

We suggest that being cast outside of the organization for performing one's duty and/or protecting the public interest, under conditions of acute mental strain, represents a powerful form of normative violence exercised by organizations over individuals who dissent, which is reliant upon the affective connections between the whistleblower and the (subject-constitutive) organization. These acute strains are exacerbated by the relentless pressures of precarious living relating to the loss of livelihood, profession and income typically experienced by whistleblowers who are forced to leave, or give up their fight for what they feel is right. These were not only materially and affectively experienced, but the relations between subject and discourse were inherently ambivalent as people found themselves constructing their positions in relation to a discourse that acted to hurt them. In addition to the above theoretical contributions, the study has practical implications.

\section{Practical Implications and Further Research}

These dynamics had real impacts upon people's struggles. Publicizing problems with mental health and using this to delegitimize a whistleblower is an effective tactic because it draws on social stigma that continues to surround even the smallest hint of mental health issues (Corrigan and Watson 2002). It is damaging at many levels because it can lead to a self-reinforcing cycle; those who experience retaliation can frequently suffer from a range of health issues, including mental health ones, and often seek counseling at some point in the process. Thus, reactions to whistleblowing by and within organizations, including retaliation, can produce negative mental health effects, which are then used by the organization to discredit the whistleblower. Moreover, suffering in such cases cannot be voiced and thus remains taboo: internalized, silenced and ongoing. In the cases of Tudor, Peter and Michael, for example, such strains led them to give up their struggle to disclose information about serious corruption, and to accept a settlement rather than continue to fight in the courts. Arguably the experiences of whistleblowers, including those taking part in this study, act to discourage others from challenging social and organizational norms even if these support wrongdoing and corruption (Alford 2001), and thus solidify organizational power.

We saw how mental health issues were actively suppressed by whistleblowers out of fear of additional stigma. The practical effect of this is to render the impact of whistleblowing on mental health and subsequent retaliation invisible, thus protecting the organization from accusations that their actions have harmed these individuals. This is particularly pertinent in light of recent moves by countries across the world to implement whistleblower protection legislation (European Commission 2014), much of which focuses on issues of employer retaliation (OECD 2012). Our study suggests that policy-makers along with those responsible for designing and implementing whistleblower speak-up arrangements ought to account for the silencing of mental health issues in cases of whistleblower retaliation.

While we have aimed to make explicit our role in this research and to engage our interviewees through workshops and other forms of feedback, future studies might usefully draw on methodologies that enable participants to further collaborate in the 'un-doing' of organizational norms through the co-production of research accounts (Riach et al. 2016), including through a more detailed exploration of affective dynamics, and of the complexity of discourses involved. Finally, while these propositions aim to emphasize normative power and its influence over whistleblowers, we do not wish to propose that subjects who find themselves excluded and 'de-realized' (author/s forthcoming) are predetermined to remain both, active participants and 'victims' of such processes. Rather the ongoing performativity of discourses including of mental health is necessarily indeterminate (Butler 1990, 2009), allowing whistleblowers and researchers working with whistleblowers to intervene by undermining these from within. This ensures that resistance, while difficult, is always possible even amidst the most oppressive organizational frameworks; further studies into whistleblower experiences might usefully explore this in the context of mental health and beyond.

\section{Conclusion}

The aim of this article was to investigate dynamics of power in whistleblower retaliation, particularly in relation to exclusion and stigmatization, as it is performed via mental illness. Our study showed how a discursive nexus in which issues of mental health and exclusion are intertwined, and work through each other, emerges in these situations. The findings from the study's empirical data drawing on a recent, in-depth exploration of whistleblowers experiences demonstrate how and why they are caught in a 'double jeopardy.' On the one hand, whistleblowers are retaliated against because of their disclosures, which harms their mental health and well-being, and they are then seen as unreliable and untrustworthy outcasts because of the suffering that the wrongdoing organizations inflicted upon them in the first place. On the other hand, they rely on the mental health discourse to draw attention to their plight and to defend the validity of their claims. This places whistleblowers in an unbearable situation. In addition to disciplining those who transgressed implicit organizational rules through their whistleblowing, 
the discursive nexus described here effectively legitimized violence against these subjects by deploying mental health discourses. Such ruthless deployment of power is possible because of the presence of social norms that we all uphold that implicitly query the reliability of those suffering from mental health issues including whistleblowers. However, by framing their postdisclosure experience in terms of the existing discourses on mental health, whistleblowers are made unwittingly complicit in their own subjectification/oppression by retaliating organizations. The overall result can be a diverting of attention away from serious wrongdoing and onto the individual, despite whistleblowers' disclosures representing one of our most important bulwarks against organizational wrongdoing. Academic research can further exacerbate this problem. Yet as the performative power of discourses is indeterminate and unstable, researchers working closely with whistleblowers have the potential to disrupt and overturn these from within.

Acknowledgements This study was funded by British Academy (GB)/ Leverhulme Trust (Grant no. SG122608).

\section{Compliance with Ethical Standards}

Conflict of interest Kenny declares that she has no conflict of interest. Fotaki declares that she has no conflict of interest. Scriver declares that she has no conflict of interest.

Ethical approval All procedures performed in studies involving human participants were in accordance with the ethical standards of the authors' institutional ethical committees.

Informed consent Informed consent was obtained from all individual participants included in the study.

Open Access This article is distributed under the terms of the Creative Commons Attribution 4.0 International License (http://creativeco mmons.org/licenses/by/4.0/), which permits unrestricted use, distribution, and reproduction in any medium, provided you give appropriate credit to the original author(s) and the source, provide a link to the Creative Commons license, and indicate if changes were made.

\section{References}

Ainsworth, S., \& Hardy, C. (2012). Subjects of inquiry: Statistics, stories, and the production of knowledge. Organization Studies, 33, $1693-1714$.

Alford, C. F. (2001). Whistleblowers: Broken lives and organizational power. Ithaca, NY: Cornell University Press.

Armenakis, A. (2004). Making a difference by speaking out: Jeff Wigand says exactly what's on his mind. Journal of Management Inquiry, 13, 355-362.

Barratt, E. (2003). Foucault, HRM and the ethos of the critical management scholar. Journal of Management Studies, 40, 1069-1087.

Biddle, L., Cooper, J., Owen-Smith, A., Klineberg, E., Bennewith, O., Hawton, K., et al. (2013). Qualitative interviewing with vulnerable populations: Individuals' experiences of participating in suicide and self-harm based research. Journal of Affective Dissorders, 145, 356-362.

Bjørkelo, B. (2013). Workplace bullying after whistleblowing: Future research and implications. Journal of Managerial Psychology, 28, 306-323.

Bolsin, S., Faunce, T., \& Oakley, J. (2005). Practical virtue ethics: Healthcare whistleblowing and portable digital technology. Journal of Medical Ethics, 31, 612-618.

Borgerson, J. L. (2005). Judith Butler: On organizing subjectivities. Sociological Review, 53, 63-79.

Burrows, J. (2001). Telling tales and saving lives: Whistleblowingthe role of professional colleagues in protecting patients from dangerous doctors. Medical Law Review, 9, 110-129.

Butler, J. (1990). Gender trouble: Feminism and the subversion of identity. New York: Routledge.

Butler, J. (1993). Bodies that matter: On the discursive limits of 'sex'. London: Verso.

Butler, J. (1997a). The psychic life of power: Theories in subjection. London: Routledge.

Butler, J. (1997b). Excitable speech: A politics of the performative. London: Routledge.

Butler, J. (2004a). Undoing gender. London: Verso.

Butler, J. (2004b). Precarious life: The powers of mourning and violence. London: Verso.

Butler, J. (2009). Frames of war: When is life grievable?. London: Verso.

Chambers, S. (2007). Normative violence after 9/11: Rereading the politics of gender trouble. New Political Science, 29, 43-60.

Corrigan, P. W. (Ed.). (2005). On the stigma of mental illness: Practical strategies for research and social change. Washington, DC: American Psychological Association.

Corrigan, P. W., \& Watson, A. C. (2002). The paradox of self-stigma and mental illness. Clinical Psychology-Science and Practice, 9, 35-53.

Devine, T., \& Maassarani, T. (2011). The corporate whistleblower's survival guide. Oakland: Berrett-Koehler.

Dworkin, T. M., \& Baucus, M. S. (1998). Internal vs. external whistleblowers: A comparison of whistleblowing processes. Journal of Business Ethics, 17(12), 1281-1298.

Ethics Resource Centre. (2012). Inside the mind of a whistleblower. Available at http://www.ethics.org/resource/inside-mind-whist leblower. Accessed November 9, 2015.

Ethics Resource Centre. (2014). National business ethics survey. Available at http://www.ethics.org/nbes. Accessed November 9, 2015.

European Commission. (2014). EU anti-corruption report, Brussels 3.2.1014, COM (2014) 38.

Ewing, D. W. (1983). Do it my way-Or you're fired! Employee rights and the changing role of management prerogatives. New York: Wiley.

Fotaki, M. (2014). Can consumer choice replace trust in the National Health Service in England? Towards developing an affective psychosocial conception of trust in health care. Sociology of Health \& Illness, 36, 1276-1294.

Foucault, M. (1976/2006). History of madness. In J. Khalfa, (Ed.), (J. Murphy, Tran.). New York: Routledge.

General Medical Council. (2015). The handling by the General Medical Council of cases involving whistleblowers. Available at http://www.gmc-uk.org/Hooper_review_final_60267393.pdf. Accessed 17 April 2018

Gilmore, S., \& Kenny, K. (2015). Work-worlds colliding: Self-reflexivity, power and emotion in organizational ethnography. Human Relations, 68, 55-87.

Grant, C. (2002). Whistleblowers: Saints of secular culture. Journal of Business Ethics, 39, 391-399. 
Hammersley, M., \& Atkinson, P. (1995). Ethnography: Principles in practice. London: Routledge.

Harding, N. (2003). The social construction of management: Texts and identities. London: Routledge.

Harding, N. (2007). On Lacan and the 'becoming-ness' of organizations/selves. Organization Studies, 28, 1761-1773.

Harding, N. (2008). The 'I', the 'me' and the 'you know': Identifying identities in organizations. Qualitative Research in Organizations and Management, 3, 42-58.

Harding, N., Ford, J., \& Fotaki, M. (2013). Is the 'F'-word still dirty? A past, present and future of/for feminist and gender studies in Organization. Organization, 20, 51-65.

Harding, N., Lee, H., \& Ford, J. (2014). Who is the middle manager? On constituting an organizational self. Human Relations, 67, 1213-1237.

Hardy, C., \& Thomas, R. (2015). Discourse in a material world. Journal of Management Studies, 52, 680-696.

Hersch, M. A. (2002). Whistleblowers-Heroes or traitors?: Individual and collective responsibility for ethical behaviour. Annual Reviews in Control, 26, 243-262.

Holloway, W., \& Jefferson, T. (2000). Doing qualitative research differently: Free association, narrative and the interview method. London: Sage.

Hook, D. (2007). Foucault, psychology and the analytics of power. Basingstoke: Palgrave.

Jackson, D., Peters, K., Andrew, S., Edenborough, M., Halcomb, E., Luck, L., et al. (2010). Trial and retribution: A qualitative study of whistleblowing and workplace relationships in nursing. Contemporary Nurse: A Journal for the Australian Nursing Profession, 36, 34-44.

Jubb, P. B. (1999). Whistleblowing: A restrictive definition and interpretation. Journal of Business Ethics, 21, 77-94.

Kenny, K. (2010). Beyond ourselves: Passion and the dark side of identification in an ethical organization. Human Relations, 63, $857-873$.

Kenny, K. (2012). "Someone big and important": Identification and affect in an international development organization. Organization Studies, 33, 1175-1194.

Kenny, K. (2017). Censored: Impossible speech and financial sector whistleblowers. Human Relations. https://doi. org/10.1177/0018726717733311.

Knights, D., \& McCabe, D. (2003). Governing through teamwork: Reconstituting subjectivity in a call centre. Journal of Management Studies, 40, 1587-1619.

Lennane, K. J. (1993). Whistleblowing: A health issue. BMJ, 307, 667-670.

Lennane, J. (1996/2012). What happens to whistleblowers, and why? Social Medicine, 6, 249-258.

Lindebaum, D., \& Gabriel, Y. (2016). Anger and organization studies: From social disorder to moral order. Organization Studies, 37, 903-918.

Lloyd, M. (2005). Butler antigone and the state. Contemporary Political Theory, 4, 451-468.

Mansbach, A. (2011). Whistleblowing as fearless speech: The radical democratic effects of late modern parrhesia. In D. Lewis \& W. Vandekerckhove (Eds.), Whistleblowing and democratic values. Available at https://www.academia.edu/1348441/Whist leblowing_and_Democratic_Values_free_ebook_. Accessed September 20, 2016.

Markova, G., \& Folger, R. (2012). Every cloud has a silver lining: Positive effects of deviant coworkers. The Journal of Social Psychology, 152, 586-612.

Martin, B., \& Rifkin, W. (2004a). The dynamics of employee dissent: Whistleblowers and organizational Jiu-Jitsu. Public Organization Review: A Global Journal, 4, 221-238.
Martin, B., \& Rifkin, W. (2004b). The dynamics of employee dissent: Whistleblower and organizational Jiu-Jitsu. Public Organization Review: A Global Journal, 4(3), 221-238.

McLain, D. L., \& Keenan, J. P. (1999). Risk, information, and the decision about response to wrongdoing in an organisation. Journal of Business Ethics, 19(3), 255-271.

Mesmer-Magnus, J. R., \& Viswesvaran, C. (2005). Whistleblowing in organizations: An examination of correlates of whistleblowing intentions, actions, and retaliation. Journal of Business Ethics, 62, 277-297.

Miceli, M. P., \& Near, J. P. (1992). Blowing the whistle: The organizational and legal implications for companies and employees. New York: Lexington.

Miceli, M. P., \& Near, J. P. (1994). Relationships among value congruence, perceived victimization, and retaliation against whistle- blowers: The case of internal auditors. Journal of Management, 20, 773-794.

Miceli, M. P., \& Near, J. P. (2002). What makes whistle-blowers effective? Three field studies. Human Relations, 55(4), 455-479.

Miceli, M. P., Rehg, M., Near, J. P., \& Ryan, K. C. (1999). Can laws protect whistle-blowers? Results of a naturally occurring field experiment. Work and Occupations, 26, 129-151.

Miethe, T. D. (1999). Whistle-Blowing at work: Tough choices in exposing fraud, waste and abuse on the job. Boulder, CO: Westview Press.

Morrison, E., \& Milliken, F. (2003). Speaking up, remaining silent: The dynamics of voice and silence. Journal of Management Studies, 40, 1353-1358.

Mumby, D. (2005). Theorizing resistance in organization studies: A dialectical approach. Management Communication Quarterly, $19,19-44$.

Near, J. P., Dworkin, T. M., \& Miceli, M. P. (1993). Explaining the whistle-blowing process: Suggestions from power theory and justice theory. Organization Science, 4, 393-411.

Near, J. P., \& Jensen, T. C. (1993). The whistle-blowing process: Retaliation and perceived effectiveness. Work Occupations, 10, 3-28.

Near, J. P., \& Miceli, M. P. (1985). Organizational dissidence: The case of whistle-blowing. Journal of Business Ethics, 4, 1-16.

Near, J. P., \& Miceli, M. P. (1986). Retaliation against whistleblowers: Predictors and effects. Journal of Applied Psychology, 71, 137-145.

Newton, T. (1998). Theorizing subjectivity in organizations: The failure of Foucauldian studies? Organization Studies, 19, 415-447.

OECD. (2012). G20 anticorruption action plan. Protection of Whistleblowers. Available at https://www.oecd.org/g20/topics/anti-corru ption/48972967.pdf. Accessed September 25, 2016.

Parker, I. (2005). Lacanian discourse analysis in psychology: Seven theoretical elements. Theory and Psychology, 15, 163-182.

Parmerlee, M. A., Near, J. P., \& Jensen, T. C. (1982). Correlates of whistleblowers' perceptions of organizational reprisals. Administrative Science Quarterly, 27, 17-34.

Paul, R., \& Townsend, J. (1996). Don't kill the messenger! Whistleblowing in America-A review with recommendations. Employee Responsibilities and Rights Journal, 9, 149-161.

Pavon-Cuellar, D. (2010). From the conscious interior to an exterior unconscious: Lacan, discourse analysis and social psychology. London: Routledge.

Peters, K., Luck, L., Hutchinson, M., Wilkes, L., Andrew, S., \& Jackson, D. (2011). The emotional sequelae of whistleblowing: Findings from a qualitative study. Journal of Clinical Nursing, 20, 2907-2914.

Premeaux, S., \& Bedeian, A. (2003). Breaking the silence: The moderating effects of self-monitoring in predicting speaking up in the workplace. Journal of Management Studies, 40, 1537-1562. 
Rehg, M. T., Miceli, M. P., Near, J. P., \& Van Scotter, J. R. (2008). Antecedents and outcomes of retaliation against whistleblowers: Gender differences and power relationships. Organization Science, 19, 221-240.

Rhodes, C., \& Wray-Bliss, E. (2013). The ethical difference of organization. Organization, 20, 40-50.

Riach, K., Rumens, N., \& Tyler, M. (2014). Un/doing chrononormativity: Negotiating ageing, gender and sexuality in organizational life. Organization Studies, 35, 1677-1698.

Riach, K., Rumens, N., \& Tyler, M. (2016). Towards a Butlerian methodology: Undoing organizational performativity through anti-narrative research. Organization Studies. https://doi. org/10.1177/0018726716632050.

Richards, L. (2005). Handling qualitative data: A practical guide. London: Sage Publications.

Rizq, R. (2013). States of abjection. Organization Studies, 34, $1277-1297$.

Roberts, J. (2005). The power of the "imaginary" in disciplinary processes. Organization, 12, 619-642.

Rothschild, J. (2013). The fate of whistleblowers in nonprofit organizations. Nonprofit and Voluntary Sector Quarterly, 42, 886-901.

Rothschild, J., \& Miethe, T. D. (1999). Whistle-blower disclosures and management retaliation: The battle to control information about organization corruption. Work and Occupations, 26, 107-128.

Stavrakakis, Y. (2008). Peripheral vision: subjectivity and the organized other: Between symbolic authority and fantasmatic enjoyment. Organization Studies, 29, 1037-1059.

Thomas, P. G. (2005). Debating a whistle-blower protection act for employees of the government of Canada. Canadian Public Administration, 48, 147-184.
Townley, B. (1993). Foucault, power/knowledge, and its relevance for Human Resource Management. The Academy of Management Review, 18, 518-545.

Tyler, M., \& Cohen, L. (2008). Management in/as comic relief: Queer theory and gender performativity in "The Office". Gender, Work and Organization, 15, 113-132.

Vandekerckhove, W., Brown, A. J., \& Tsahuridu, E. E. (2014). Managerial responses to whistleblowing. In A. J. Brown, D. Lewis, R. Moberly, \& W. Vandekerkhove (Eds.), International handbook on whistleblowing research (pp. 298-327). Cheltenham: Edward Elgar.

Vandekerckhove, W., \& Tsahuridu, E. E. (2010). Risky rescues and Whistleblowing. Journal of Business Ethics, 97(3), 365-380.

Varman, R., \& Al-Amoudi, I. (2016). Accumulation through derealization: How corporate violence remains unchecked. Human Relations, 69(10), 1909-1935.

Walker, M. T. (2006). The social construction of mental illness and its implications for the recovery model. International Journal of Psychosocial Rehabilitation, 10(1), 71-87.

Wilmot, S. (2000). Nurses and whistleblowing: The ethical issues. Journal of Advanced Nursing, 32, 1051-1057.

Worth, M. (2013). Whistleblowing in Europe: Legal protections for whistleblowers in the EU, transparency international. Available http://www.transparency.org/whatwedo/publication/whistleblo wing_in_europe_legal_protections_for_whistleblowers_in_the eu. Accessed 17 April 2018.

Wray-Bliss, E. (2003). Research subjects/research subjections: Exploring the ethics and politics of critical research. Organization, 10, $307-325$. 